Cadernos Walter Benjamin 25

\title{
POR UMA ÉTICA JUDAICA DA NÃO-VIOLÊNCIA: JUDITH BUTLER LEITORA DE WALTER BENJAMIN
}

\author{
Ricardo Araújo Dib Táxi \\ Nilton Augusto Duarte das Chagas
}

\begin{abstract}
RESUMO
Uma das leituras mais proeminentes de Benjamin na filosofia contemporânea é, sem dúvida alguma, aquela que Judith Butler promove. Em suas teorizações sobre ética e filosofia política, marcadamente mais presentes desde o início do século, Benjamin auxilia Butler a refletir sobre as mais variadas temáticas, desde a crítica do progresso até sobre um novo pensar a respeito do judaísmo. A este texto interessa a reconstrução da leitura que realiza Butler de Para a crítica da violência, texto "incompreensível" e polêmico do "jovem" Benjamin, leitura esta fundamental para suas teorizações sobre a violência e a construção uma ética da não-violência, ainda latente em Caminhos divergentes. Pouco aceita por certos círculos benjaminianos, Butler consegue fazer, com sua construção crítico-normativa, a expansão da vivacidade de Benjamin para pensar o presente, reavivando no centro do debate político-filosófico o pensar sobre a violência do direito e, necessariamente, do Estado.
\end{abstract}

Palavras-chave: Judaicidade. Violência. Não-violência. Ética. Crítica

\section{FOR A JEWISH ETHICS OF NON-VIOLENCE: JUDITH BUTLER READER BY WALTER BENJAMIN}

\begin{abstract}
One of Benjamin's most prominent readings in contemporary philosophy is undoubtedly the one that Judith Butler promotes. In her theorizations about ethics and political philosophy, which have been markedly more present since the beginning of the century, Benjamin helps Butler to reflect on the most varied themes, from the criticism of progress to a new thinking about Judaism. This text is interested in the reconstruction of the reading by Butler of Critique of violence, an "incomprehensible" and controversial text by the "young" Benjamin, fundamental reading for her theorizations about violence and for the construction of an ethics of non-violence, still latent in Parting ways. Not widely accepted in certain Benjaminian circles, Butler manages to expand, with her critical-normative construction, Benjamin's vivacity to think the present, reviving at the center of the political-philosophical debate the thinking about violence of law and, therefore, of the State.
\end{abstract}

Professor Doutor na Universidade Federal do Pará, vinculado ao Instituto de Ciências Jurídicas. Leciona no Programa de pós-graduação em Direito da mesma Universidade. Brasileiro, residente em Belém. E-mail: ricardoadt@gmail.com

Graduando em Direito pela Universidade Federal do Pará (UFPA) e pesquisador de Iniciação Científica PIBIC/FAPESPA em Filosofia pela mesma universidade. Brasileiro, residente em Belém. E-mail: nilton.chagas@hotmail.com 
Keywords: Jewishness. Violence. No violence. Ethic. Criticism

\section{Introdução}

Desde Vida Precária (2004), livro que marca, de algum modo, a virada estilística e filosófica de Judith Butler para a construção de seu projeto teórico que conhecemos hoje, podemos perceber o teor investigativo de suas reflexões. Para além de temáticas também tratadas, como os conceitos de vulnerabilidade, precariedade, luto público e a relação entre política institucional e violência, podemos perceber uma espécie de proposição normativa, mesmo que de caráter "fraco": a construção do que ela chama por "ética da não-violência". Não à toa seu último livro, publicado em fevereiro deste ano, tem como título The Force of Non-Violence (A Força da Não-Violência). Butler é muito clara no último ensaio de Vida Precária: "Delinearei o que me parece ser os contornos de uma possível ética judaica da não violência" (BUTLER, 2019, 160), interpretando, naquele momento, o conceito levinasiano de "rosto".

Tais reflexões marcam o campo de trabalho de Judith Butler primordialmente desde o 11 de Setembro de 2001, grande marco político (e geopolítico) do início do século no Ocidente. Embora mantendo em muitos escritos as teorizações marcadas pelas temáticas de gênero e sexualidade, as quais jamais deixaram ter relevância fundamental em seus trabalhos, Butler tem se aprofundado em construções filosóficas mais próximas do que comumente chamamos por filosofia política e/ou ética. ${ }^{1}$ Isso fez com que ela abandonasse certos pressupostos marcadamente fortes em seus trabalhos, como a recusa total de qualquer tipo de universalismo (muito presente nos seus ensaios de Debates Feministas), e assumisse outros, como ela mesma nos diz em entrevista recente para a revista Margem Esquerda: "curiosamente, eu trabalho hoje em dia mais centrada na teoria crítica do que no pós-estruturalismo" (BUTLER,

\footnotetext{
1 "publicações recentes de Judith Butler têm mostrado que seu pensamento vai além do universo teórico e político do feminismo, das questões de gênero de sexualidade e da teoria queer, abarcando também reflexões éticas, políticas e ontológicas decisivas para pensar as relações entre vida, filosofia e política no mundo contemporâneo [...] isto não significa que a autora tenha abandonado a reflexão sobre gênero e sexualidade, e a publicação de Undoing Gender de 2004, é prova disto, dentre inúmeras outras" (DUARTE, 2016, 311 - 315)
}

Professor Doutor na Universidade Federal do Pará, vinculado ao Instituto de Ciências Jurídicas. Leciona no Programa de pós-graduação em Direito da mesma Universidade. Brasileiro, residente em Belém. E-mail: ricardoadt@gmail.com

Graduando em Direito pela Universidade Federal do Pará (UFPA) e pesquisador de Iniciação Científica PIBIC/FAPESPA em Filosofia pela mesma universidade. Brasileiro, residente em Belém. E-mail: nilton.chagas@hotmail.com 
2019, 17). Nesta mudança de perspectiva teórica se inclui o diálogo com novos autores e autoras a partir de novos interesses, como Emmanuel Lévinas, Hannah Arendt e, fundamentalmente, Walter Benjamin - reflexões conexas que giram em torno de uma ética do Outro, do estado, da violência e da memória.

Neste artigo, as pretensões são modestas. Não se trata de fazer uma grande genealogia do que poderia significar uma "ética judaica da não-violência", perpassando por reflexões da tradição teológica judaica ou algo do gênero. $O$ que interessa a este trabalho é a apropriação feita por Judith Butler da obra de Walter Benjamin, mais centralmente de seu clássico e "incompreensível" ensaio Para a crítica da violência. ${ }^{2}$ Tal apropriação feita com o intuito de sustentar sua proposta de construção de uma prática política performativa da não-violência. A discussão, aqui, entorna o judaísmo pelo fato de que é em um livro dedicado a reflexões sobre a judaicidade, a crítica e o sionismo que Judith Butler escreve seu ensaio apropriativo deste texto de Benjamin, com a finalidade de refletir sobre a violência impetrada pelo Estado de Israel contra os palestinos e, a partir disso, construir sua proposição do que ela chama por "ética judaica da não violência", qual seja, a compreensão de certa tradição judaica fundamentalmente marcada pela prática político-religiosa da nãoviolência, o que demonstraria a contradição de um Estado-nação - que reivindica para si a centralidade do judaísmo - marcado pelas práticas militaristas violentas. Butler procura, então, a partir de Benjamin, traçar "caminhos divergentes" da perspectiva ética, política e judaica praticada pelo Estado de Israel.

Portanto, diferentemente do texto de Benjamin Brum sobre as aproximações entre Butler e Benjamin, ${ }^{3}$ esse texto busca inicialmente esclarecer e expor o contexto

\footnotetext{
${ }^{2}$ Zur Kritik der gewalt (título do ensaio no original) possui algumas traduções para o português - como as de Willi Bolle e de João Barrento. Aqui nos é útil a última tradução do texto no Brasil, realizada por Ernani Chaves em livro organizado por Jeanne Marie Gagnebin. Por isso, sempre que fizermos referência ao título do ensaio, o faremos pela tradução dada por Ernani Chaves.

${ }^{3}$ A apropriação de Benjamin Brum sobre a relação entre Judith Butler e Walter Benjamin, apesar de perpassar pela crítica da violência, foca principalmente na crítica do progresso em ambas as figuras, partindo das Teses e se utilizando, primordialmente, do terceiro capítulo de Quadros de Guerra, o que faz seu texto diametralmente diferente das pretensões aqui apontadas. Ver: BRUM, Benjamin. Judith Butler leitora de Walter Benjamin: para uma crítica das políticas progressistas e identitárias. São Paulo: Cadernos de Filosofia Alemã, 2019.
}

Professor Doutor na Universidade Federal do Pará, vinculado ao Instituto de Ciências Jurídicas. Leciona no Programa de pós-graduação em Direito da mesma Universidade. Brasileiro, residente em Belém. E-mail: ricardoadt@gmail.com

Graduando em Direito pela Universidade Federal do Pará (UFPA) e pesquisador de Iniciação Científica PIBIC/FAPESPA em Filosofia pela mesma universidade. Brasileiro, residente em Belém. E-mail: nilton.chagas@hotmail.com 
do livro Caminhos Divergentes, de Judith Butler, para que se adentre mais profundamente e se reconstrua sua apropriação e interpretação da crítica da violência em Walter Benjamin, demonstrando a vivacidade do filósofo - mesmo que para as reflexões concretas sobre a política contemporânea de um Estado que reivindica para si o judaísmo. Por fim, a partir desta interpretação de Para a crítica da violência, se quer demonstrar aqui que o significado de um rumo ao messiânico, de uma violência divina que destitui a violência mítica, pode ser pensado como a construção de uma proposição ética contemporânea, também demonstrando que uma ética da nãoviolência não é simplesmente "pacifismo" ou sinônimo de "passividade" política, podendo ser a práxis não-violenta um ato transformador e revolucionário, para que seja sempre direcionada em nome dos viventes.

\section{Caminhos divergentes para a convergência}

O judaísmo e a judaicidade atravessam a obra e a vida de Judith Butler de maneira bastante marcante. Como judia, Butler falou em diversas entrevistas sobre a influência de uma formação escolar, literária e filosófica judaica ao longo de seus caminhos de desenvolvimento intelectual. ${ }^{4}$ Em sua obra, a temática judaica se torna mais explícita a partir de temas que versam a política e a geopolítica, mas também primordialmente a ética. É desde seu ensaio $A$ acusação de antissemitismo: Judeus, Israel e os Riscos da crítica pública, presente no livro Vida Precária, que tal temática aparece mais proeminentemente (não esquecendo, claro, de seu ensaio interpretativo sobre Levinás neste mesmo livro, marcadamente judaico). Não à toa grande parte dos autores e autoras com quem Butler está dialogando a partir de sua virada ontológico-

\footnotetext{
${ }^{4} \mathrm{Em}$ entrevista para a revista Margem Esquerda da editora Boitempo, Butler é contundente: "fui obrigada a estudar filosofia com o rabino como uma espécie de "punição" por ter me comportado mal nas aulas do curso regular da escola hebraica (...) Então ele perguntou o que me interessava, e mencionei a ética existencial, a excomunhão de Spinoza da Sinagoga na Holanda e se a filosofia alemã tinha influenciado a ideologia nazista (...) A estrutura inicial para todo meu pensamento filosófico foi a filosofia judaica, assim como minhas formas iniciais de pensar a filosofia" (BUTLER, 2019, 14, grifo nosso).

Professor Doutor na Universidade Federal do Pará, vinculado ao Instituto de Ciências Jurídicas. Leciona no Programa de pós-graduação em Direito da mesma Universidade. Brasileiro, residente em Belém. E-mail: ricardoadt@gmail.com

Graduando em Direito pela Universidade Federal do Pará (UFPA) e pesquisador de Iniciação Científica PIBIC/FAPESPA em Filosofia pela mesma universidade. Brasileiro, residente em Belém. E-mail: nilton.chagas@hotmail.com
} 
normativa ${ }^{5}$ são judeus e incorporam em suas obras elementos da tradição e teologia judaicas.

O próprio título de seu livro Caminhos Divergentes (Parting Ways) vem da inspiração de um trecho dos Jewish Writings de Hannah Arendt. Ao tratar sobre e criticar duas vertentes do judaísmo político na década de 1930 - os chamados assimilacionistas e os sionistas - em relação a elementos diaspóricos e à Palestina, Arendt diz: "trata-se, nos dois casos, da mesma deficiência, que surge de um medo judaico comum de admitir que existem e sempre existiram interesses divergentes entre os judeus e os grupos dos povos com os quais eles vivem" (ARENDT apud BUTLER, 2018, 138, grifo nosso). O título nasce da expressão "interesses divergentes" usada por Arendt para explicitar a inafastabilidade de certa condição judaica de convivência com o que é divergente, com o que é propriamente não judaico - e mesmo com um diferente tipo de concepção judaica - e disto resultará certa perspectiva normativa para a proposição de Butler sobre o binacionalismo 6 entre judeus e palestinos na região hoje sob controle do Estado de Israel. Butler quer mostrar que "a persistência de 'interesses divergentes' não constitui fundamentos nem para a absorção, nem para a separação" (BUTLER, 2018, 138), ou seja, a contingência de caminhos divergentes pode ser a possibilidade compreensiva de certa abertura para a convergência, desde uma específica visão sobre elementos da judaicidade que tem implicações éticas plurais.

Em todo caso, como afirma a autora já na introdução de Caminhos Divergentes, o primeiro passo para empreender uma crítica judaica à violência de Estado praticada

${ }^{5}$ Nos utilizamos aqui de expressão utilizada por André Duarte (2016) em seu texto sobre Hannah Arendt e Judith Butler para caracterizar as diferenças estruturais e teóricas ao longo do desenvolvimento da obra de Butler.

6 Proposta que converge a apreensão teórica de Butler em relação aos autores trabalhados por ela no livro, seja Said, Arendt ou Benjamin. Isto fica mais claro nesta passagem do livro: "Essa adjacência não escolhida, esse viver com os outros e em contraposição a eles, pode perfeitamente se tornar a base para um binacionalismo que busque desfazer o nacionalismo (...) Essa coabitação seria guiada pela memória e pelo apelo à justiça que surge da despossessão, do exílio e da contenção forçada, não só para dois povos, mas para todos os povos" (BUTLER, 2018, 181, grifo nosso). Importante atentar para estes elementos convergentes, como a temática do binacionalismo muito tratada por Said, a coabitação por Arendt e a memória por Benjamin.

Professor Doutor na Universidade Federal do Pará, vinculado ao Instituto de Ciências Jurídicas. Leciona no Programa de pós-graduação em Direito da mesma Universidade. Brasileiro, residente em Belém. E-mail: ricardoadt@gmail.com

Graduando em Direito pela Universidade Federal do Pará (UFPA) e pesquisador de Iniciação Científica PIBIC/FAPESPA em Filosofia pela mesma universidade. Brasileiro, residente em Belém. E-mail: nilton.chagas@hotmail.com 
por Israel é afastar o argumento sionista segundo o qual toda a crítica a Israel é necessariamente anti-semita (BUTLER, 2017, 11). Tal redução de toda e qualquer crítica à reafirmação do preconceito totaliza o debate e impossibilita que se perceba que o próprio significado da judaicidade está aqui em disputa e não pode ser simplesmente igualado a qualquer posição tomada pelo Estado de Israel. Nesse sentido, afirma a autora que "se eu conseguir mostrar que existem recursos judaicos para a crítica da violência de Estado, da subjugação colonial das populações, da expulsão e da despossessão, terei conseguido mostrar que uma crítica judaica da violência de Estado Israelense é, pelo menos, possível - talvez até eticamente obrigatória (BUTLER, 2017, 11). Apesar de não ser o foco de Butler ao tratar sobre Benjamin e a crítica da violência, é relevantíssimo demarcar as relações controversas deste com o pensar de um Estado judaico, ou um nacionalismo judaico. Como lembra Bernd Witte (2017, 24-25), "Benjamin se afastava do sionismo como movimento político e social, pois ao 'nacionalismo' sionista contrapunha-se diametralmente a vocação do judaísmo para uma 'vontade cultural radical' de natureza supranacional”. ${ }^{7}$ Isto, de algum modo, é fundamental para o que Butler trata em Caminhos divergentes.

Ao se quebrar a hegemonia de uma única voz a falar em nome da tradição judaica, se torna possível perceber uma pluralidade de posições bastante distintas, algumas das quais totalmente opostas à ideia de violência de Estado e mesmo do conceito de nação tal como desenvolvido pelo argumento sionista. Resgatando a figura teológica de Moisés como um egípcio, Butler enxerga no centro do judaísmo a questão da convivência com o outro, da relacionalidade, o que inclusive se torna mais claro quando se pensa em uma ética diaspórica.

Entretanto, ainda que seja possível derivar da própria tradição judaica os princípios de uma ética crítica ao nacionalismo sionista, a permanência nesse horizonte terminaria por reiterar uma espécie de primazia do quadro de referência judaico. Por essa razão, o próprio movimento de busca na tradição judaica de uma

\footnotetext{
7 "Não achei que os sionistas tornaram a sua vida judaica, que tinham mais do que vagas representações do espírito judaico" (BENJAMIN, 1991, 838). Devemos a lembrança desta citação, assim como sua tradução, a Ernani Chaves.
}

Professor Doutor na Universidade Federal do Pará, vinculado ao Instituto de Ciências Jurídicas. Leciona no Programa de pós-graduação em Direito da mesma Universidade. Brasileiro, residente em Belém. E-mail: ricardoadt@gmail.com

Graduando em Direito pela Universidade Federal do Pará (UFPA) e pesquisador de Iniciação Científica PIBIC/FAPESPA em Filosofia pela mesma universidade. Brasileiro, residente em Belém. E-mail: nilton.chagas@hotmail.com 
ética permeada pela relação com o outro leva Butler a estender o argumento para além das fronteiras da judaicidade. O desenvolvimento da ideia de uma ética judaica permeada pela relacionalidade torna difícil falar em valores exclusivamente judaicos, pois "a relacionalidade desloca a ontologia" (BUTLER, 2017, 15).

É verdade que os argumentos centrais de Caminhos Divergentes são extraídos de diálogos que se dão eminentemente com autores judeus, como é o caso de Benjamin, Levinás, Arendt e Primo Levi. Entretanto, mesmo quando está dialogando, por assim dizer, dentro do quadro de referência judaico, Butler está a todo o tempo mostrando que a distinção entre dentro e fora, entre um núcleo definidor do judaico e aquilo que pode ser tido como exterior é em si mesma problemática, pois o ser judeu é a todo momento atravessado por essa coabitação.

A partir da leitura feita por Edward Said em Freud e os não europeus ${ }^{8}$ da tese freudiana da ascendência egípcia de Moisés, Butler mostra como a percepção de que na fundação do judaísmo se encontra um estrangeiro é relevante para repensar toda a questão da relacionalidade e da pertença do outro na fundação da tradição judaica. O texto de Said, vale ressaltar, representou inclusive uma espécie de porta de entrada para os estudos pós-coloniais na psicanálise.

Esse atravessamento da coabitação não significa, por outro lado, que o judeu não exista ou, como afirmou Sartre, que o antissemita crie o judeu. Butler se afasta explicitamente dessa afirmação sartreana, posto que seu objetivo não é desfazer a figura do judeu, mas desconstruir a teologia sionista que pensa um povo isolado, que foi expulso de uma terra natal e agora tem a missão histórica e religiosa de recuperála. Além de argumentos históricos que mostram que a diáspora foi uma das condições que possibilitou a sobrevivência do povo judaico, Butler pretende pensar essa dispersão não apenas como uma questão histórica ou política, mas como a base para pensar uma ética judaica para além do nacionalismo e da exclusão do outro (BUTLER, 2017).

\footnotetext{
${ }^{8}$ Ver: SAID, Edward. Freud e os não-europeus. São Paulo: Boitempo, 2004.

Professor Doutor na Universidade Federal do Pará, vinculado ao Instituto de Ciências Jurídicas. Leciona no Programa de pós-graduação em Direito da mesma Universidade. Brasileiro, residente em Belém. E-mail: ricardoadt@gmail.com

Graduando em Direito pela Universidade Federal do Pará (UFPA) e pesquisador de Iniciação Científica PIBIC/FAPESPA em Filosofia pela mesma universidade. Brasileiro, residente em Belém. E-mail: nilton.chagas@hotmail.com
} 
É nesse contexto que se torna questionável todo argumento que transforma a violência de Estado em necessidade histórica, justificando posteriormente o apagamento do outro. Se, com Levinás, Butler pôde pensar a questão da interpelação do outro e da responsabilidade que a vulnerabilidade do outro me traz, com Benjamin a filósofa questionará justamente a legitimação mítica da violência enquanto destino, ou seja, como um elemento inevitável e necessário para a consolidação de uma ordem construída como necessidade histórica.

Ademais, Butler dialoga com Benjamin para pensar também o apagamento do povo palestino, que foi desempossado de suas casas e terras quando da criação do Estado de Israel e hoje só são perceptíveis como escombros de um passado esquecido, como o Odradek de Kafka que um dia pode ter tido forma humana, mas hoje é irreconhecível. Aqui, Butler articula mais especificamente as Teses sobre $o$ conceito de história para pensar justamente como narrar a história silenciada dos oprimidos.

Neste trabalho, contudo, o objeto é a leitura que a filósofa norte-americana fez de Para a crítica da violência embora vez por outra seja indispensável mencionar outros elementos da obra benjaminiana.

\section{Violência como poder. Violência como não-violência?}

Antes de entrar na interpretação butleriana do texto de Benjamin, se faz necessário apontar alguns elementos relativos ao contexto histórico de produção do texto, bem como ao percurso filosófico trilhado pelo filósofo por ocasião da elaboração do ensaio.

Como apontou Rafael Vieira em sua tese de doutoramento intitulada Walter Benjamin: o direito, a política e a ascensão e colapso da república de Weimar, ${ }^{9}$ é impossível apartar o texto benjaminiano para uma crítica da violência do contexto da república de Weimar. Embora não se deva buscar mergulhar as teses filosóficas

\footnotetext{
9 Ver: VIEIRA, Rafael. Walter Benjamin: O direito, a política e a ascensão e colapso da República de Weimar (1918/9-1933). Rio de Janeiro, 2016. 248p. Tese de Doutorado - Departamento de Direito. Pontifícia Universidade Católica do Rio de Janeiro.
}

Professor Doutor na Universidade Federal do Pará, vinculado ao Instituto de Ciências Jurídicas. Leciona no Programa de pós-graduação em Direito da mesma Universidade. Brasileiro, residente em Belém. E-mail: ricardoadt@gmail.com

Graduando em Direito pela Universidade Federal do Pará (UFPA) e pesquisador de Iniciação Científica PIBIC/FAPESPA em Filosofia pela mesma universidade. Brasileiro, residente em Belém. E-mail: nilton.chagas@hotmail.com 
inteiramente na tinta dos acontecimentos históricos e políticos, seria igualmente errôneo desconsiderar como as ocorrências históricas influenciaram a redação do ensaio.

Também Jeanne Marie Gagnebin, na obra Walter Benjamin e os Cacos da História, ${ }^{10}$ relembra os acontecimentos que circundaram a criação da República de Weimar como elementos históricos imprescindíveis para se compreender o texto benjaminiano de 1921.

Em Dezembro de 1918, ocorria na Alemanha uma radicalização de movimentos de trabalhadores que havia começado já no fim da guerra com as manifestações populares organizadas pelos soldados da marinha alemã, as quais rapidamente se espalharam entre várias classes de trabalhadores e deram o impulso que destruiria de vez a Alemanha Imperial (WEITZ, 2018).

Entretanto, as forças políticas do partido social-democrata, lideradas por Friedrich Ebert, trabalharam para encurtar e disciplinar as manifestações, pois temiam que a Revolução Russa fosse replicada na Alemanha. Assim, entre o fim de dezembro de 1918 e os primeiros meses de 1919, as lideranças em torno do partido socialdemocrata se aliaram aos militares para suprimir os conselhos de trabalhadores, organizando inclusive formações paramilitares às quais foi dada licença para exercer extrema violência (WEITZ, 2018, 26). ${ }^{11}$

Dentre os movimentos populares que foram massacrados estava a liga Spartakus, que defendia a socialização das grandes empresas, propriedades, bancos e minas, pretendendo continuar a revolução iniciada no fim de 1918 sob a premissa de uma radicalização da democracia na Alemanha. O grupo também foi perseguido por Noske, o que culminou no assassinato de vários de seus membros, incluindo Rosa Luxemburgo e Karl Liebknetch, além de operários insurgentes por toda a Alemanha (VIEIRA, 2016, 23).

10 Ver: GAGNEBIN, Jeanne Marie. Walter Benjamin e os cacos da história. São Paulo: N-1 Edições, 2018.

11 "During a Strike wave and workers uprising two months later, SPD defender Minister Gustav Noske, issued an order that every person who is found fighting with arms in the hand against government troops is to be immediately shot" (WEITZ, 2018, 31).

Professor Doutor na Universidade Federal do Pará, vinculado ao Instituto de Ciências Jurídicas. Leciona no Programa de pós-graduação em Direito da mesma Universidade. Brasileiro, residente em Belém. E-mail: ricardoadt@gmail.com

Graduando em Direito pela Universidade Federal do Pará (UFPA) e pesquisador de Iniciação Científica PIBIC/FAPESPA em Filosofia pela mesma universidade. Brasileiro, residente em Belém. E-mail: nilton.chagas@hotmail.com 
Esses acontecimentos tiveram um impacto relativo na vida pessoal de Benjamin que em 1917 fora para a Suíça com a então esposa para cuidar de sua saúde $^{12}$, mas foram significativos em sua produção intelectual da época, gerando uma série de debates a respeito do direito de greve e da distinção com a qual a Alemanha, que havia defendido a revolução para derrubar o Império, rapidamente viu uma aliança entre os militares e a classe dominante criminalizar e exterminar violentamente as tentativas de revolução popular.

Foi ainda na Suíça que Benjamin teve contato com os textos de Georges Sorel a respeito da violência e do direito de greve, os quais teriam uma grande importância em sua crítica da violência. Também de seu tempo na Suíça há registros de diversas cartas trocadas com Scholem nas quais começa a aparecer uma relação entre mito e o direito como uma ordem violenta que surge não em oposição, mas justamente a partir de uma lógica mítica de perpetuação da culpa e da figura do destino.

Do ponto de vista das marcas e influências teóricas que à época apareciam em seus escritos, Löwy destaca a complexa associação entre anti-capitalismo romântico, messianismo judaico e anarco-socialismo, que apareceriam em seus escritos até 23, tomando posteriormente outras formas.

Vieira documentou o início das discussões de Benjamin sobre o direito por volta de 1916, o que pode ser atestado por suas conversas com Scholem, qualificando a lei como uma ordem que só poderia ser fundamentada por meio do mito (VIEIRA, 2016). Benjamin vê no mito uma categoria que se articula impedindo que os seres humanos se percebam como seres históricos capazes de ter liberdade sobre 0 desenvolvimento de sua vida e de sua história.

Não é fácil mapear o modo como Benjamin lida com a questão do mito. Ernani Chaves lembra a interpretação adorniana segundo a qual "para vencer as forças do mito Benjamin precisa assemelhar-se a ele, vestir sua roupagem para melhor combatê-lo" (CHAVES, 2003, 15).

\footnotetext{
${ }^{12}$ Como também lembra Ernani Chaves, Benjamin partiu para a Suíça como refugiado da Guerra em busca da neutralidade do país como maneira de "expressar seu protesto "pacifista" (CHAVES, 1994, 24).
}

Professor Doutor na Universidade Federal do Pará, vinculado ao Instituto de Ciências Jurídicas. Leciona no Programa de pós-graduação em Direito da mesma Universidade. Brasileiro, residente em Belém. E-mail: ricardoadt@gmail.com

Graduando em Direito pela Universidade Federal do Pará (UFPA) e pesquisador de Iniciação Científica PIBIC/FAPESPA em Filosofia pela mesma universidade. Brasileiro, residente em Belém. E-mail: nilton.chagas@hotmail.com 
Já no texto Destino e Caráter, de 1919, é possível antever claramente algumas das questões que seriam fundamentais em Para a crítica da violência, em 1921. Dentre elas se encontra a relação entre mito, culpa e direito. Ao contrário da leitura tradicional que vê a ordem jurídica como o triunfo da racionalidade sobre o mito, Benjamin vê o direito como irmão gêmeo da violência e a ordem jurídica como uma perpetuação da maldição do destino mítico. Ernani Chaves $(2003,21)$ o diz nos seguintes termos:

O direito aparece, portanto, como a perpetuação da ordem mítica nas sociedades que pensavam tê-la eliminado. $O$ juiz pode encontrar em todos os atos humanos a ação inexorável do destino; o processo de julgamento penal descreve no seu termo não mais um homem, mas um homem puro e simples, uma vida simples, natural, vida entre outras vidas, determinada na sua aparência pela sua participação natural no universo da culpa e da infelicidade. É justamente essa naturalização da culpa que torna o direito um resíduo do plano demoníaco da existência humana.

Assim, apesar de seus diálogos em Caminhos Divergentes com Primo Levi e Hannah Arendt quanto às suas respectivas posições a respeito do sionismo, Judith Butler, no que se refere à sua leitura de Walter Benjamin, não está interessada diretamente neste ponto de discussão. Aqui, como suas reflexões a partir de Benjamin em geral, o problema que interessa a Butler é aquele que parte do "jovem" Benjamin, mais especificamente no seu famoso texto sobre a violência, Para a crítica da violência, tão debatido ao longo do século XX por uma série de intérpretes. ${ }^{13}$ "Estou menos interessada nas questões específicas que ele levantou sobre o Sionismo (...) do que estou quando às suas próprias visões sobre violência, e sobre a violência legal em particular” (BUTLER, 2017, 75, trad. mod.), diz ela. Deste modo, no capítulo 3 de Caminhos Divergentes Butler busca compreender de que maneira Benjamin se utiliza de fontes teóricas judaicas e não judaicas para pensar "uma crítica da violência legal - o tipo de violência que estados cometem precisamente por meio de sua estrutura legal" (Idem, 75, trad. mod). O ponto de Butler em sua apropriação de Benjamin neste quesito é uma espécie de contraposição a certo lugar-comum da filosofia política

\footnotetext{
${ }^{13}$ Poderíamos citar, por exemplo, Derrida, Arendt e, mais recentemente, Agamben, Balibar e muitos outros e outras - assim como Butler, é claro.

Professor Doutor na Universidade Federal do Pará, vinculado ao Instituto de Ciências Jurídicas. Leciona no Programa de pós-graduação em Direito da mesma Universidade. Brasileiro, residente em Belém. E-mail: ricardoadt@gmail.com

Graduando em Direito pela Universidade Federal do Pará (UFPA) e pesquisador de Iniciação Científica PIBIC/FAPESPA em Filosofia pela mesma universidade. Brasileiro, residente em Belém. E-mail: nilton.chagas@hotmail.com
} 
liberal desde Hobbes, a qual compreende que a lei seria uma espécie de alternativa à violência, suscitando as possibilidades de recusa e resistência a este tipo de enquadramento. ${ }^{14}$

Um dos interesses conceituais de Butler quanto à obra de Benjamin é o problema do messiânico, e as diferentes formas e significados que este assume no decorrer de suas reflexões sobre o termo. Em A Tarefa do Tradutor, segundo Butler, o messiânico constituiria uma ruptura quanto à possibilidade de transmissão. Em Para crítica da violência o messiânico como violência divina ainda constituiria uma ruptura, mas desta vez uma ruptura quanto à violência do direito e uma escusa da culpa. Desse modo, Butler pretende considerar que "o messiânico é um esforço contradoutrinal para romper com regimes temporais que produzem culpa, obediência, que ampliam a violência legal, e encobrem a história dos oprimidos" (Idem, 76, trad. mod.). O messiânico é a ruptura quanto ao "engrandecimento do mundo dos culpados" e, portanto, uma ruptura em relação aos quadros do direito e da violência. ${ }^{15}$

Retornando ao seu ensaio de 1921, Butler aponta que a pergunta mais elementar talvez seja: qual o sentido precisamente de crítica aqui? A resposta de Butler: "Uma crítica da violência é uma investigação sobre as condições para a violência, mas é também uma interrogação sobre como a violência é circunscrita de antemão a partir das perguntas que colocamos sobre ela" (BUTLER, 2017, 76, trad. mod.). Portanto, de fato e inevitavelmente, o termo crítica aqui assumiria um teor que Ihe é comum desde Kant, qual seja, o criticar da violência estaria marcado pelo questionar das condições de possibilidade da violência - como bem aponta Ernani Chaves em sua tradução do ensaio. Mas aqui há um elemento certamente novo, um elemento apropriativo de Butler em relação a Benjamin: a crítica é uma interrogação sobre o modo que a violência é circunscrita a partir das perguntas que fazemos a

${ }^{14}$ A crítica ao liberalismo é pedra fundamental na construção ético-político de Butler, e um dos marcadores essenciais de seu último livro, em que ela também mobiliza este ensaio de Benjamin em relação ao conceito de framework (BUTLER, 2020, 124).

15 Benjamin é, de algum modo, devedor de Nietzsche e sua Genealogia da Moral neste ponto de associação entre culpa (Schuld) e direito. O pensar sobre a culpa/dívida é mais evidente em textos anteriores, como, por exemplo, Capitalismo como religião, influenciado por certo entusiasmo por Nietzsche, muito comum à época (GAGNEBIN, 2014, 189).

Professor Doutor na Universidade Federal do Pará, vinculado ao Instituto de Ciências Jurídicas. Leciona no Programa de pós-graduação em Direito da mesma Universidade. Brasileiro, residente em Belém. E-mail: ricardoadt@gmail.com

Graduando em Direito pela Universidade Federal do Pará (UFPA) e pesquisador de Iniciação Científica PIBIC/FAPESPA em Filosofia pela mesma universidade. Brasileiro, residente em Belém. E-mail: nilton.chagas@hotmail.com 
respeito dela. ${ }^{16}$ Não à toa, no ensaio, no que se refere à ética, Benjamin fala sobre o imperativo categórico e "seu programa mínimo absolutamente incontestável" ao mesmo tempo em que reconhece que este programa "não é em si suficiente para essa crítica" (BENJAMIN, 2011, 133), qual seja, a crítica da violência. Este elemento é melhor tratado por Butler no terceiro capítulo de seu último livro, mas é importante demarcar desde já que a ideia de crítica da violência em Benjamin, segundo Butler, parte necessariamente de um avaliar sobre a forma como esta está circunscrita, a forma como esta aparece, a forma como ela é enquadrada em certos regimes de linguagem na esfera pública - uma questão certamente pós-kantiana, e que provavelmente guarda elementos de uma apropriação foucaltiana de Benjamin.

Porém, ultrapassada esta afirmação de Butler sobre o sentido de crítica, a filósofa americana afirma que, para ela, o ensaio de Benjamin é contundentemente uma crítica da violência do direito, e nesta crítica Benjamin ofereceria dois tipos diferentes de explicação, e a partir disso pergunta: de que modo a violência do direito se faz possível e o que é o direito ao ponto de necessitar da violência? Além disso, o que é a violência no modo em que assume sua forma legal? O que o leva à questão fundamental do ensaio: existiria alguma outra forma de violência "que é não-coercitiva, uma violência que pode ser invocada e empreendida contra a coerção?", ou, mais radicalmente ainda, "existiria um tipo de violência que não é somente empreendida contra a coerção, mas é em si mesma não-coercitiva e, neste sentido - se não em outros, fundamentalmente não-violenta?” (BUTLER, 2017, 77, grifo nosso). Para Butler, portanto, a questão sobre uma violência não-violenta exerce dois papéis no ensaio, quais sejam, a forma de questionamento sobre a possibilidade de tal questão, e ao mesmo tempo a forma da proposição ou, em termos contemporâneos, de normatividade - pois a ela interessa, justamente, pensar uma ética da não-violência. Portanto, é como se Benjamin estivesse perguntando sobre a condição de

${ }^{16}$ Este é o ponto central da interpretação que Butler faz do ensaio em The Force of Non-violence, temática a ser tratada em outro texto.

Professor Doutor na Universidade Federal do Pará, vinculado ao Instituto de Ciências Jurídicas. Leciona no Programa de pós-graduação em Direito da mesma Universidade. Brasileiro, residente em Belém. E-mail: ricardoadt@gmail.com

Graduando em Direito pela Universidade Federal do Pará (UFPA) e pesquisador de Iniciação Científica PIBIC/FAPESPA em Filosofia pela mesma universidade. Brasileiro, residente em Belém. E-mail: nilton.chagas@hotmail.com 
possibilidade deste tipo paradoxal de violência e, simultaneamente, a estivesse prescrevendo como solução para o problema da violência como direito.

É importante lembrar neste ponto que Butler não está fazendo aqui um trabalho de comentadora ou de exegeta de Benjamin, o que sequer se pretendeu ser. Butler está desenvolvendo suas teorias sobre política e ética em diálogo com autores e autoras, entre os quais está Benjamin que abre o caminho para pensar a violência de Estado. Portanto, sua interpretação apropriativa de Benjamin não é a palavra final sobre a "verdade" de Benjamin - o que, é conveniente dizer, seria muito difícil de se estabelecer. E é neste tom apropriativo que Butler continua e demarca que Benjamin se refere a esta violência não-coercitiva como "não-sangrenta", parecendo implicar que não seria direcionada a corpos e vidas humanas. Contudo, como foi dito, não se trata de uma palavra final, mas de uma possibilidade interpretativa: "no fim não fica claro se ele consegue cumprir esta promessa"17, porém, continua: "espero levar em consideração, nas páginas seguintes, essa possibilidade [a de uma violência não violenta] no ensaio de Benjamin" (BUTLER, 2017, 78).

Como certo senso comum aos leitores de Benjamin, o ensaio de 1921 é particularmente obscuro em uma série de pontos. Porém, segundo Butler, é necessário trabalhar dois grupos básicos de distinções para entender o que Benjamin está pretendendo. O primeiro deles é aquele que distingue entre a violência que instaura o direito (rechtsetzend) e aquela que mantém o direito (rechtserhaltend). A mantenedora representaria o esforço institucional repetido de garantir que o direito "continue exercendo seu caráter vinculante sobre a população que governa". A instauradora, diferentemente, seria a forma da violência em que o direito é colocado como um feito do surgimento de uma determinada ordem política; e, em ambas, as forças militares representariam um nexo institucional ambíguo como força instauradora e mantenedora ao mesmo tempo. Claramente, neste ponto, Benjamin se contrapõe a certas percepções sobre a fundação de uma ordem jurídica, como as

17 Butler aponta para tal indeterminação tendo em vista as passagens em que Benjamin fala sobre a Coré (BENJAMIN, 2011, 151), assim como poderíamos apontar a ambiguidade de passagens do ensaio, como a crítica ao militante pacifista Kurt Hiller (Idem, 153).

Professor Doutor na Universidade Federal do Pará, vinculado ao Instituto de Ciências Jurídicas. Leciona no Programa de pós-graduação em Direito da mesma Universidade. Brasileiro, residente em Belém. E-mail: ricardoadt@gmail.com

Graduando em Direito pela Universidade Federal do Pará (UFPA) e pesquisador de Iniciação Científica PIBIC/FAPESPA em Filosofia pela mesma universidade. Brasileiro, residente em Belém. E-mail: nilton.chagas@hotmail.com 
baseadas no estabelecimento de um contrato que culminaria na fundação do direito como instrumento de harmonização social. Benjamin é contundente contra esta perspectiva: o que instaura o direito e o funda em uma ordem política é um ato de violência, e tal ato se repete continuamente em seu esforço mantenedor. E é somente a partir desta instauração violenta que se dão as condições de justificação e de deliberação a respeito da justificação.

Dito isso, chega-se à conclusão de que o núcleo da violência que instaura o direito se resume na afirmação de "isto será lei" ou, mais enfaticamente, "isto agora é lei". Butler então chega a outros conceitos fundamentais do ensaio de Benjamin: "Essa última concepção da violência legal - a que instaura o direito - é entendida como uma operação do destino, termo que tem um sentido específico para Benjamin" pois "o destino pertence ao campo helênico do mito, e a violência que mantém o direito é, de muitas maneiras, o subproduto dessa violência que instaura o direito, porque o direito que é mantido é exatamente o direito que já foi instaurado" (BUTLER, 2017, 78). Temos aqui dois elementos conceituais fundamentais do ensaio de Benjamin: as ideias de destino e de mito. A associação entre destino e violência do direito não aparece ex nihilo em Para uma crítica da violência. Em verdade, além das motivações político-biográficas, a problemática do destino está presente desde o texto Destino e Caráter, de 1919. Na sua tentativa de desconectar destino e religião, Benjamin busca associar justamente destino com a culpa, assim como com a infelicidade, partindo das experiências do trágico - "na clássica formulação grega da ideia de destino" - no que se relaciona ao campo do direito (CHAVES, 1994, 18). A "balança do direito" seria uma espécie de ordenação, um domínio, em que a infelicidade e a culpa são conceitos constitutivos, e dentro dos quais "não há nenhuma via pensável de libertação" (BENJAMIN, 2011, 93). Portanto, tais conceituações, como aparecem em Para uma crítica da violência, não são inéditas; são desenvolvimentos de elementos já tratados anteriormente por Benjamin em Destino e caráter. Butler trata mais profundamente sobre estes conceitos em seus comentários sobre o mito de Níobe e nos elementos teológico-helênicos dos conceitos.

Professor Doutor na Universidade Federal do Pará, vinculado ao Instituto de Ciências Jurídicas. Leciona no Programa de pós-graduação em Direito da mesma Universidade. Brasileiro, residente em Belém. E-mail: ricardoadt@gmail.com

Graduando em Direito pela Universidade Federal do Pará (UFPA) e pesquisador de Iniciação Científica PIBIC/FAPESPA em Filosofia pela mesma universidade. Brasileiro, residente em Belém. E-mail: nilton.chagas@hotmail.com 
Para que se compreenda o que é a violência seja em seu modo instaurador ou mantenedor, deve-se considerar outra violência que não pode ser entendida pela ideia de destino, nem como violência "mítica". A violência mítica é a que estabelece o direito sem qualquer justificativa, sem qualquer deliberação. Como dito acima, o que instaura o direito é um ato de violência, e sua deliberação justificativa vem depois. Citamos Butler (2017, 72-73, trad. mod.) longamente:

\begin{abstract}
o direito é fundado sem justificação, sem referência à justificação, mesmo que faça referência à justificação possível como consequência de sua fundação. Primeiro o sujeito é vinculado ao direito, depois surge um quadro legal para justificar o quadro vinculante do direito. Como consequência, produzem-se sujeitos que têm de responder pelo direito perante o direito, que passam a se definir por sua relação com a responsabilização legal. Tendo em conta esse campo do direito em suas duas instâncias, a fundadora e a preservadora, Benjamin postula uma "violência divina", uma violência que visa o mesmo quadro de referência que estabelece a responsabilização legal. A violência mística é desencadeada contra a força coercitiva desse quadro legal (legal framework), contra a responsabilização que vincula o sujeito a um sistema legal específico e o impede de desenvolver um ponto de vista crítico, quiçá revolucionário, sobre esse sistema legal. Quando um sistema legal precisa ser desfeito, ou quando sua coercitividade leva a uma revolta por parte de quem sofre sua coerção, é importante que esses vínculos de responsabilização sejam rompidos. Na verdade, fazer a coisa certa de acordo com a lei estabelecida é justamente aquilo que deve ser suspenso a fim de dissolver um conjunto de leis estabelecidas que é injusto.
\end{abstract}

Há muita coisa a dizer sobre esse trecho. Primeiramente, sobre a troca elocucionária da voz que fala e da voz que representa, ou seja, Butler transita entre sua própria "voz" e a "voz" que ela representa, neste caso a de Benjamin; veja-se, por exemplo, o uso do termo "produzem-se sujeitos", claramente vocabulário de Judith Butler herdado, com suas devidas particularidades, de Michel Foucault. Benjamin pode querer falar sobre produção subjetiva, mas jamais utilizaria tal tipo de elocução. Outro ponto interessante sobre essa transição de "vozes" é o uso do conceito de framework, que significa quadro ou enquadramento. Vocabulário tipicamente butleriano incorporado primordialmente em seu livro Frames of War, largamente influenciada pela sociologia de Erving Goffman, a ideia de framework vem estabelecer certas similaridades e interações com Foucault em seus conceitos de regimes de verdade, ou regimes de saber-poder e nas reflexões em torno de instituições e Professor Doutor na Universidade Federal do Pará, vinculado ao Instituto de Ciências Jurídicas. Leciona no Programa de pós-graduação em Direito da mesma Universidade. Brasileiro, residente em Belém. E-mail: ricardoadt@gmail.com

Graduando em Direito pela Universidade Federal do Pará (UFPA) e pesquisador de Iniciação Científica PIBIC/FAPESPA em Filosofia pela mesma universidade. Brasileiro, residente em Belém. E-mail: nilton.chagas@hotmail.com 
poderes. Claramente, portanto, não se trata de linguagem de Benjamin, mas da apropriação que Butler faz de seu texto. Outra questão fundamental é o trecho final que Butler mesmo destaca. O fazer de acordo com a lei é o que deve ser suspenso, portanto, a ação em vista de deposição do quadro legal é um não-fazer, o que não necessariamente significa uma não-ação. Isto tem implicações fundamentais para o desenvolvimento de uma ética da não-violência e será melhor esclarecido posteriormente.

Este não-fazer de acordo com a lei é justamente o argumento de Georges Sorel que influencia fundamentalmente a visão de Benjamin sobre a greve geral, aquela que leva à dissolução do aparelho estatal, e que ele utiliza como exemplo fundamental para a diferenciação entre "violência sancionada" e "violência não-sancionada" (BENJAMIN, 2011, 125). A greve geral tem como intenção desfazer toda a base legal de determinado Estado. Benjamin agrega a esta concepção sua leitura do messiânico enquanto fenômeno teológico-político. Esta aproximação de um não-fazer enquanto ação voltada à certa estrutura legal é um dos elementos fundantes para a leitura que Butler faz de Benjamin enquanto propositor da não-violência, o que não faz dele, segundo Butler $(2017,79)$, necessariamente um anarquista:

\begin{abstract}
Benjamin não diz em lugar nenhum que é preciso se opor a todos os sistemas legais, e nesse texto não fica claro se ele se opõe a certos Estados de direito e não a outros. Além disso, se nesse ponto ele conversa com o anarquismo, deveríamos pelo menos pensar um pouco sobre o que o anarquismo significaria nesse contexto, tendo em mente que Benjamin leva a sério o mandamento "Não matarás". Paradoxalmente, Benjamin vislumbra a libertação da responsabilização legal e da culpa como um caminho para a compreensão do sofrimento e da transitoriedade da vida, da vida como algo que nem sempre pode ser explicado pelo quadro de responsabilização moral ou legal. Essa compreensão do sofrimento e da transitoriedade pode levar, segundo ele, a um tipo de felicidade.
\end{abstract}

Há neste trecho também fundamentalmente dois elementos essenciais da apropriação que Butler faz de Benjamin. O primeiro deles é a sua afirmação sobre a necessidade de se pensar, caso se queira ver Benjamin como um apologeta do

Professor Doutor na Universidade Federal do Pará, vinculado ao Instituto de Ciências Jurídicas. Leciona no Programa de pós-graduação em Direito da mesma Universidade. Brasileiro, residente em Belém. E-mail: ricardoadt@gmail.com

Graduando em Direito pela Universidade Federal do Pará (UFPA) e pesquisador de Iniciação Científica PIBIC/FAPESPA em Filosofia pela mesma universidade. Brasileiro, residente em Belém. E-mail: nilton.chagas@hotmail.com 
anarquismo ${ }^{18}$, sobre qual tipo de anarquismo seria este, visto que "Benjamin leva a sério o mandamento 'Não matarás'”. Butler destrinchará melhor o ponto do mandamento. Porém, o que é interessante destacar é a presença de certa compreensão ética do ensaio benjaminiano; ou seja, não se trata de um anarquismo em que seu fim - o derrubar das forças estatais - tenha alto direcionamento e potência política, mas não tenha certa forma de vida (ou que esta forma de vida seja marcada por um certo hedonismo infantil). O que Butler está dizendo é que, caso haja um anarquismo em Benjamin, não se trata de uma auto referencialidade. Há aqui uma substancialidade ética, um ethos, uma forma de vida que, esta sim, fundamentaria pretensões que se podem chamar de anarquistas. Esta ética seria aquela que leva a sério o mandamento "Não matarás". Butler faz referência à libertação da responsabilização legal em Benjamin não tendo como consequência a libertação de toda e qualquer responsabilização, pois isto seria o fim da ética. Como diz o próprio Benjamin no ensaio, tal crítica da violência "tão pouco - se não se quer proclamar um anarquismo francamente infantil - [pode] ser obtida pela recusa em reconhecer toda e qualquer imposição em relação à pessoa", visto que "tal máxima simplesmente exclui a reflexão quanto à esfera ético histórica e, com isso, quanto a qualquer sentido de ação (...)" (BENJAMIN, 2011, 132, grifo nosso).

O outro ponto fundamental desta citação é a sua segunda parte, fazendo referência à ideia de que a libertação da responsabilização legal e da culpa seria caminho para a compreensão do sofrimento e da transitoriedade da vida, compreensão a qual "pode levar, segundo ele, a um tipo de felicidade". Butler faz referência aqui clara e direta ao fim do Fragmento Teológico-Político, texto contemporâneo a Para a crítica da violência, para propor uma chave interpretativa

18 Biograficamente, como bem aponta Ernani Chaves (1994, 24), é praticamente inegável certo "anarquismo confesso" neste "jovem" Benjamin, fortemente influenciado por sua leitura de Sorel e seus debates políticos com Scholem e Bloch durante seu período de refúgio na Suíça em virtude da Primeira Guerra. Outros elementos a este respeito também podem ser encontrados no texto de Michel Löwy, L'anarchisme messianique de Walter Benjamin. Geralmente, em uma leitura apressada, pode-se inferir que, ao tratar de greve geral revolucionária, Benjamin estaria demarcando seu marxismo e, portanto, um posicionamento comunista. Em verdade, o seu tipo de marxismo, explícito nas Teses, ganha força somente a partir de 1924, por influência de Asja Lacis.

Professor Doutor na Universidade Federal do Pará, vinculado ao Instituto de Ciências Jurídicas. Leciona no Programa de pós-graduação em Direito da mesma Universidade. Brasileiro, residente em Belém. E-mail: ricardoadt@gmail.com

Graduando em Direito pela Universidade Federal do Pará (UFPA) e pesquisador de Iniciação Científica PIBIC/FAPESPA em Filosofia pela mesma universidade. Brasileiro, residente em Belém. E-mail: nilton.chagas@hotmail.com 
fundamental sobre a ideia de mito e da violência mítica. Cito o trecho do fragmento (BENJAMIN, 2012, 24):

À restitutio in integrum espiritual, que leva à imortalidade, corresponde uma outra, profana, que conduz à eternidade de uma dissolução; e o ritmo dessa ordem do profano eternamente transitório, transitório na sua totalidade, na sua totalidade espacial, mas também temporal, o ritmo da natureza messiânica, é a felicidade.

Essa pode ser uma das chaves de leitura para o muitas vezes incompreensível Fragmento Teológico-Político. A responsabilização legal e a culpa representam o enrijecimento subjetivo, temporal e espacial (ou seja, guardam consigo certa concepção unitária sobre espacialidade e temporalidade) ${ }^{19}$ - sujeito este que Benjamin denomina por "sujeito do destino" (BENJAMIN, 2011, 94), que pode equivaler ao "indivíduo enquanto sujeito do direito" (Idem, 126). Não à toa, a violência mítica instauradora do direito, representada pelo mito de Niobe, é aquela que faz com que Niobe se transforme em pedra. Assim, a libertação em relação a estes dois elementos pode ser um caminho para a transitoriedade, para uma outra concepção sobre tempo e espaço e sobre a subjetividade. Esta ordem do profano ${ }^{20}$ eternamente transitório seria a felicidade, justamente o contrário do domínio jurídico, como antecipado em Destino e caráter, locus por excelência no qual a "medida da pessoa" (Idem, 93), é a infelicidade e a culpa.

Além de Sorel, Benjamin trabalhou com suas fontes judaicas, como Scholem e Cohen, para a elaboração deste ensaio, anexando a perspectiva teológica à política

19 "O nexo de culpa é temporal num sentido inteiramente inapropriado, pois é completamente diferente, no modo e na medida, do tempo da redenção ou do tempo da música ou do tempo da verdade" (BENJAMIN, 2011, 95, grifo nosso). Como bem indica Ernani Chaves, o tempo do destino é o da "repetição", o tempo que sempre retorna, parasitário, regido por outras determinações que não a da liberdade (CHAVES, 1994, 21-22) e, portanto, diferente do tempo da redenção.

${ }^{20}$ A ideia do profano é fundamental para compreender o uso que Benjamin faz da teologia, visto que seu pensamento é caracterizado pelo pensar da política e da História a partir de categorias teológicas, mas marcadamente não religiosas. Sem distinguir teologia e religião não se pode compreender o pensamento de Benjamin, visto que "as figuras teológicas e messiânicas comprovam sua eficácia suprema ao serem totalmente absorvidas pelo mundo profano", distanciando-se, portanto, das figuras sagradas e religiosas, funcionando como uma espécie de "complexo metafórico texto/escrita" (GAGNEBIN, 2014, 191).

Professor Doutor na Universidade Federal do Pará, vinculado ao Instituto de Ciências Jurídicas. Leciona no Programa de pós-graduação em Direito da mesma Universidade. Brasileiro, residente em Belém. E-mail: ricardoadt@gmail.com

Graduando em Direito pela Universidade Federal do Pará (UFPA) e pesquisador de Iniciação Científica PIBIC/FAPESPA em Filosofia pela mesma universidade. Brasileiro, residente em Belém. E-mail: nilton.chagas@hotmail.com 
para pensar sobre "as condições para uma greve geral que resultasse na paralisação e dissolução de todo um sistema legal e, de outro, a noção de um deus divino cujo mandamento oferece um tipo de injunção irredutível ao direito coercitivo" (BUTLER, 2017, 79). Porém, para Butler, o que dá fundamento a este tipo de injunção teológica é uma outra fonte sobre o judaísmo: a figura de Franz Rosenzweig, mais especificamente em seu trabalho The Star of Redemption. ${ }^{21}$ A violência divina em Benjamin é "comunicada por um mandamento que não é nem despótico nem coercitivo (...) não é vinculante nem imposto pela violência legal” (Idem). A compreensão de que a ideia de mandamento não é um imperativo, um ato despótico ou de coerção aproxima-se da compreensão de mandamento de Rosenzweig que, como Butler bem aponta, compreende o mandamento como "um esforço verbal e escrito por parte de Deus para solicitar o amor de seu povo" (BUTLER, 2017, 79). Existem uma série de passagens em $A$ Star of Redemption que estão dedicadas ao conceito de mandamento enquanto solicitação de amor, e não lei. "O mandamento é absolutamente incapaz, por si só, de ser lei. Ele pode ser somente mandamento (...) o mandamento para amá-lo [Deus]" (ROSENZWEIG, 2005, 191-192, trad. nossa). Segundo Butler, é justamente este significado, ou pelo menos parte dele, que Benjamin assume para si em Para a crítica da violência, primordialmente quanto ao mandamento "Não Matarás", articulando a partir disso sua crítica da violência do Estado.

É costumeiro compreender o mandamento divino como um imperativo enquanto lei e, portanto, enquanto coerção. Porém, em Benjamin, assim como em Rosenzweig, há "um entendimento judaico diferente sobre o mandamento", pois este seria uma transmissão de "um imperativo justamente sem ter a capacidade para impor o imperativo que comunica" (BUTLER, 2017, 80). Cita-se Butler (Idem, p. 80) mais longamente sobre este ponto:

\footnotetext{
${ }^{21}$ Para uma outra aproximação entre Walter Benjamin e Rosenzweig, recomenda-se o texto de Ernani Chaves que traz a problemática do trágico em relação a estes dois autores e Nietzsche. Ver: CHAVES, Ernani. O "silêncio do trágico": Walter Benjamin entre Franz Rosenzweig e Friedrich Nietzsche. Lisboa: Philosophica, 2015.
}

Professor Doutor na Universidade Federal do Pará, vinculado ao Instituto de Ciências Jurídicas. Leciona no Programa de pós-graduação em Direito da mesma Universidade. Brasileiro, residente em Belém. E-mail: ricardoadt@gmail.com

Graduando em Direito pela Universidade Federal do Pará (UFPA) e pesquisador de Iniciação Científica PIBIC/FAPESPA em Filosofia pela mesma universidade. Brasileiro, residente em Belém. E-mail: nilton.chagas@hotmail.com 
Ele [o mandamento] não é a vocalização de um Deus furioso e vingativo. e, nessa visão, o direito judaico, de maneira mais geral, decisivamente não é punitivo; além disso, o mandamento associado ao Deus judaico aqui se opõe à culpa, até busca uma expiação da culpa que, segundo Benjamin, é uma herança específica das tradições míticas ou helênicas (...) Benjamin invoca o mandamento como uma ordem apenas para que o indivíduo lide com a determinação ética comunicada pelo imperativo. Esse imperativo não impõe, mas deixa em aberto os modos de sua aplicabilidade e suas possibilidades de interpretação, incluindo as condições em que pode ser recusado.

Apesar da apropriação de Butler do ensaio de Benjamin, isso de modo algum quereria dizer que Butler está de acordo com todas as colocações e pretensões normativas (se é que as podemos denominar assim). O que Butler está fazendo é uma interpretação apropriativa, um realocar do ensaio para pensar problemáticas que ela diagnostica no presente como deveres da crítica. Aqui, a crítica do Estado e a construção de uma ética da não-violência como melhor via para se pensar uma forma de vida baseada na coabitação, na equidade de valor das vidas, na igualdade radical e no estabelecimento da memória:

Embora Benjamin claramente se equivoque sobre a possibilidade e o sentido da não violência, sugiro que o mandamento, como concebido por Benjamin, é não só a base para a crítica da violência legal, mas também a condição para uma teoria da responsabilidade que tem em seu núcleo um esforço contínuo pela não violência. (Idem, 81, trad nossa)

Retirado o fato de que Butler não explicita em que sentido Benjamin estaria equivocado, vê-se justamente que ela não faz o trabalho de uma exegeta ou comentadora de sua obra, mas uma atualizadora a partir de inquietações sobre o presente. No caso de Caminhos Divergentes, trata-se da inquietação quanto à violência de Estado perpetrada pelo Estado de Israel contra os palestinos, "um esforço para mobilizar perspectivas críticas judaicas contra as políticas atuais" (Idem: 81); e as problemáticas que tal questão envolve quanto ao pensar sobre o judaísmo enquanto possibilidade de construção de uma nova ética que seja judaica e nãojudaica, uma nova forma relacional baseada justamente nesta transitoriedade, na nãodeterminação nacional enquanto delimitação de identidades rígidas; ou seja, um outro judaísmo que não aquele que o Estado de Israel e o sionismo que o sustenta praticam

Professor Doutor na Universidade Federal do Pará, vinculado ao Instituto de Ciências Jurídicas. Leciona no Programa de pós-graduação em Direito da mesma Universidade. Brasileiro, residente em Belém. E-mail: ricardoadt@gmail.com

Graduando em Direito pela Universidade Federal do Pará (UFPA) e pesquisador de Iniciação Científica PIBIC/FAPESPA em Filosofia pela mesma universidade. Brasileiro, residente em Belém. E-mail: nilton.chagas@hotmail.com 
e reivindicam como O Judaísmo, A Judaicidade, a prática autêntica do Ser Judeu, demonstrando que não há, propriamente, uma univocidade identitária no que se refere ao judeu; pelo contrário, a proposta butleriana para pensar o judaísmo é aquela que se refere justamente à pluralidade, à multiconvivência, ao diaspórico como determinante da coabitação e, em última instância, à igualdade radical quanto ao valor das vidas e a construção de uma práxis da não-violência enquanto direcionamento do que podemos chamar de ética.

Dessa maneira, há um afastamento em relação à compreensão do judaísmo e de seu Deus como relacionalidades vingativas, punitivistas e construtoras de culpa. É isso o que Butler gostaria de apontar como um dos pontos interessantes sobre a compreensão que Benjamin tem do judaísmo. Ela consegue ver "nas linhagens cabalísticas que influenciaram o pensamento de Benjamin um vestígio que lança luz sobre um judaísmo diferente" (Idem, 81), um judaísmo associado, relativamente, a certo movimento de oposição ao rabinismo presente nas obras de Rosenzweig e Martin Buber, ${ }^{22}$ uma judaicidade em que Jeová não é figura associada à punição ou à coerção legal, mas aquela que solicita o amor, e que, se contém em si um imperativo, é a ideia de "Amai-me!" (Idem). Diz Benjamin (2011, 152, grifo nosso):

\begin{abstract}
Estas [as formas manifestas da violência do direito] não se definem pelo fato de que Deus em pessoa exerça essa violência de modo imediato, por milagres, mas por aqueles momentos de cumprimento não-sangrento, golpeador, expiador de culpa. E, enfim, pela ausência de qualquer instauração de direito.
\end{abstract}

Seria desta perspectiva teológico-política que partiria Benjamin em seu ensaio para criticar a violência mítica, a coerção sem justificação em sua fundação e que dá ares de deliberação em sua manutenção, mas que não passa de uma repetição do

22 É importante apontar aqui os relatos biográficos que afastam Benjamin fundamentalmente das obras de Buber e Rosenzweig quanto à relação entre mito e judaísmo, visto que Benjamin estava muito mais próximo da obra de Cohen neste ponto, para quem mito e judaísmo eram essencialmente opostos um ao outro (CHAVES, 1994, 27), o que contestaria, em alguma medida, as afirmações de Butler. Aqui não cabe examinar o apontar de aproximações e afastamentos entre Benjamin, Buber e Rosenzweig, mas sim de que modo a compreensão sobre o mandamento se relaciona à mudança de certa compreensão judaica.

Professor Doutor na Universidade Federal do Pará, vinculado ao Instituto de Ciências Jurídicas. Leciona no Programa de pós-graduação em Direito da mesma Universidade. Brasileiro, residente em Belém. E-mail: ricardoadt@gmail.com

Graduando em Direito pela Universidade Federal do Pará (UFPA) e pesquisador de Iniciação Científica PIBIC/FAPESPA em Filosofia pela mesma universidade. Brasileiro, residente em Belém. E-mail: nilton.chagas@hotmail.com 
ato fundacional. Portanto, uma crítica do poder (neste caso, do direito e do Estado) enquanto violência. O direito não é, dessa perspectiva, ambiente institucional de consentimento conjunto, de estabelecimento deliberado de contrato entre indivíduos, de harmonia e paz social. O direito é violência, e é o monopólio desta; não só, propriamente, no sentido weberiano. O direito é o monopólio da violência pelo Estado não somente enquanto ato físico, mas majoritariamente sobre a circunscrição da ideia de violência na esfera pública, ou seja, sobre como devemos compreender a ideia de violência enquanto ato legítimo ou ilegítimo, enquanto ato de defesa própria ou terrorismo.

Por óbvio, Benjamin não coloca estas questões nestes termos. Benjamin sustentaria novamente que o direito é produto do destino (Schicksal) e faz sua clássica distinção entre violência mítica (que guarda consigo as formas instauradora e mantenedora) e violência divina. O destino é aquilo que dá origem, sem justificação, ao direito enquanto manifestação da fúria dos deuses - eis o porquê do uso das ideias de mito e violência mítica, em referência à "clássica formulação grega". Não tendo justificação, o direito não serve enquanto meio em vias de uma finalidade como, por exemplo, a abolição do estado de todos contra todos. O direito é um puro meio e a sua finalidade "é a própria manifestação" (Idem) deste. É por meio deste tipo de linguagem que Benjamin inicia em seu ensaio reflexões sobre o mito de Níobe, elemento que "oferece um excelente exemplo" (BENJAMIN, 2011, 147) para o que ele chama de "violência mítica" de maneira alegórica em uma ligação entre mito e poesia grega, uma concepção profundamente metafísica e, ao mesmo tempo, política (GAGNEBIN, 2014, 54).

O mito de Níobe, presente nas Fabulae de Higino, conta a história desta figura, Níobe, esposa de Anfião, o então rei de Tebas. A rainha de Tebas, muito fértil, teria tido quatorze filhos. Em determinado momento, o povo de Tebas decide realizar um tributo à deusa Leto, o que desagrada a rainha, que insulta a deusa zombando de sua infertilidade por somente ter dois filhos, Apolo e Ártemis, e requer ao povo que o culto a Leto seja interrompido. Leto então ordena o assassinato de seus filhos como punição, a ser realizado por Apolo e Ártemis, já que Níobe, mera mortal, teria a

Professor Doutor na Universidade Federal do Pará, vinculado ao Instituto de Ciências Jurídicas. Leciona no Programa de pós-graduação em Direito da mesma Universidade. Brasileiro, residente em Belém. E-mail: ricardoadt@gmail.com

Graduando em Direito pela Universidade Federal do Pará (UFPA) e pesquisador de Iniciação Científica PIBIC/FAPESPA em Filosofia pela mesma universidade. Brasileiro, residente em Belém. 
ultrajado profundamente, reivindicando para si a superioridade por conta de sua fertilidade, o que ofenderia a distinção necessária entre humanos e deuses. O ponto de Benjamin é que a punição atribuída a Níobe por Leto não é aquela marcada pela transgressão de uma lei já existente. Em verdade, Níobe, "com a petulância de seu ato de fala, ela desafia ou provoca o destino" (BUTLER, 2012, 84); desse modo, Ártemis e Apolo agem em nome do destino, ou mais propriamente agem de modo que haja uma instituição do destino, e o resultado do triunfo do destino é justamente o estabelecimento do direito. Diz Benjamin (2011, 147-148):

\begin{abstract}
É verdade que a ação de Apolo e Ártemis pode parecer apenas um castigo. Mas a violência deles é muito mais instauração de um direito do que castigo pela transgressão de um direito existente. O orgulho de Níobe atrai sobre si a fatalidade, não porque fere o direito, mas porque desafia o destino - para uma luta na qual o destino deve vencer, engendrando, somente nessa vitória, um direito [...] a violência desaba, portanto, sobre Níobe a partir da esfera incerta e ambígua do destino. Ela não é propriamente destruidora. Embora traga a morte sangrenta aos filhos de Níobe, ela também detém diante da vida da mãe, deixando a vida para trás, mais culpada do que antes por causa da morte das crianças, como portadora eterna e muda da culpa e também como marco limite entre homens e deuses.
\end{abstract}

Desse modo, como dito acima, o direito seria estabelecido por um ato de fúria dos deuses, e não é estabelecido em vistas de um fim, mas como um puro meio que se manifesta no direito em-si, autorreferencialmente. Butler compreende que "essa fúria age performativamente ${ }^{23}$ para marcar e transformar Níobe, definindo-a como culpada que assume a forma de uma rocha. $O$ direito, portanto, petrifica o sujeito, interrompendo a vida no momento da culpa" (BUTLER, 2017, 84). Na ordem mítica do destino (pode-se perceber isso em uma série de tragédias gregas) 24 "o homem é culpado por definição" (GAGNEBIN, 2014, 54). Essa economia da penitência pertenceria, para Benjamin, à esfera do mito. ${ }^{25}$ Níobe estaria "enrijecida, endurecida

${ }^{23}$ Vê-se aqui, como em outra citação acima em que Butler se refere à noção de "ato de fala", a mistura de elocuções e de vozes novamente, utilizando seus próprios conceitos desenvolvidos ao longo de toda sua obra para interpretar Benjamin.

${ }^{24} \mathrm{~A}$ associação não é livre, como já visto acima, pois é feita pelo próprio Benjamin em Destino e caráter sobre "a clássica formulação grega da ideia de destino" (BENJAMIN, 2011, 92).

${ }^{25}$ Isto pode ser encontrado em outros textos como, por exemplo, seu ensaio sobre as Afinidades Eletivas de Goethe, assim como no "Drama Barroco", no seu texto sobre Kafka de 1934 e, também, em "Destino e Caráter".

Professor Doutor na Universidade Federal do Pará, vinculado ao Instituto de Ciências Jurídicas. Leciona no Programa de pós-graduação em Direito da mesma Universidade. Brasileiro, residente em Belém. E-mail: ricardoadt@gmail.com

Graduando em Direito pela Universidade Federal do Pará (UFPA) e pesquisador de Iniciação Científica PIBIC/FAPESPA em Filosofia pela mesma universidade. Brasileiro, residente em Belém. E-mail: nilton.chagas@hotmail.com 
na culpa e pela culpa, mas ainda cheia de tristeza, lamentando eternamente naquele manancial petrificado" (Idem). Vemos aqui, novamente, o paralelo estabelecido por Butler, como visto acima, entre Para a crítica da violência e o Fragmento TeológicoPolítico; enquanto o eternamente transitório se caracteriza pela felicidade, vê-se na alegoria a partir de Níobe que a petrificação, o enrijecimento, a unidade que estabelece a culpa é o que enche de tristeza, "eternamente naquele manancial petrificado". Portanto, a crítica de Benjamin ao direito é justamente a contraposição a tais estabelecimentos punitivos, ao instaurar da culpa repetitivamente, à responsabilização eterna, forma bruta de violência que é posta pelo direito. Assim, para Benjamin, a culpa seria um estabelecimento imposto de fora, e não um reflexo de autoconsciência a partir de um ato considerado punível a priori. A culpa é uma das consequências da violência do direito, resultado do destino mítico. Assim, constituirse enquanto sujeito, nesse meio, "é assumir a responsabilidade por uma violência que precede o sujeito e cuja operação é ocluída por ele, que passa a atribuir a violência que sofre aos seus próprios atos" (BUTLER, 2017, 84); é justamente tal tipo de formação que escamoteia a violência da operação, externa ao próprio indivíduo, impondo a este toda a responsabilidade pelo que sofre.

Portanto, o contrário da ideia de destino é justamente aquilo que afasta tais condições de coerção, culpabilização e violência; ${ }^{26}$ neste caso, para a ideia de Deus, ou do divino, segundo Benjamin. Parte-se do mito (esfera do destino), para o divino, "a esfera a que pertence certa destruição não-violenta”, embora Butler não saiba, propriamente, "no que consiste essa destruição não-violenta" (BUTLER, 2017, 85) a

\footnotetext{
${ }^{26}$ Jeanne Marie vê certa inscrição da moral kantiana da autonomia como contraposto ao destino nesta leitura de Benjamin (GAGNEBIN, 2014, 56), visto que a figura do destino nas tragédias gregas é marcada por certa inevitabilidade frente aos acontecimentos, havendo um apagamento da possibilidade de autodeterminação e mudança histórica, o apagamento de uma possível redenção ou uma escolha feita de maneira autônoma que possibilite a transformação do que foi imposto, a quebra do rito - tal figura é muito clara em Édipo, por exemplo. A moral kantiana da autonomia seria, então, o contraposto e a ruptura frente ao destino. Ernani Chaves compreende da mesma maneira quando diz que a temporalidade do destino em Benjamin está longe do atingir da "maioridade", fortemente marcada por sua não-autonomia (CHAVES, 1994, 22). Tal influência do kantismo viria de Herman Cohen, filósofo neo-kantista judeu que marcou os estudos de Benjamin em Kant e sua ética, assim como de Heinrich Rickert, com quem Benjamin iniciou seus estudos em filosofia em Freiburg (WITTE, 2017, 21).

Professor Doutor na Universidade Federal do Pará, vinculado ao Instituto de Ciências Jurídicas. Leciona no Programa de pós-graduação em Direito da mesma Universidade. Brasileiro, residente em Belém. E-mail: ricardoadt@gmail.com

Graduando em Direito pela Universidade Federal do Pará (UFPA) e pesquisador de Iniciação Científica PIBIC/FAPESPA em Filosofia pela mesma universidade. Brasileiro, residente em Belém. E-mail: nilton.chagas@hotmail.com
} 
não ser o fato de que esta está dirigida ao quadro de referência legal (mesmo que não se saiba se é a todo e qualquer quadro legal). Há uma série de indefinições no ensaio de Benjamin, uma série de obscuridades não bem explicitadas, assim como ambiguidades. O autor alemão dedica um número considerável de páginas para sua leitura de Sorel e dos tipos de greve - sendo a greve política o que poderíamos chamar da greve em vistas de reforma e, portanto, mantenedora, e a greve geral proletária, aquela que justamente destrói o poder do estado e toda sua força de coerção, a própria violência legal. Talvez um dos pontos culminantes que interesse a Judith Butler neste ensaio são suas possibilidades de leitura como um ensaio que faz ode à nãoviolência, para o pensar em formas relacionais e formas de vida não violentas. De fato, Benjamin dedica uma série de páginas para tratar, direta ou indiretamente, da ideia de não-violência ${ }^{27}$, ao ponto de dizer que, enquanto a greve geral política é violenta, a greve geral proletária, "enquanto meio puro, ${ }^{28}$ é não-violenta", apesar de que esta "se propõe, como única tarefa, aniquilar o poder do Estado" (BENJAMIN, 2011, 142-143). Estes trechos são fundamentalmente relevantes para a apropriação que Butler faz do texto, pois para ela há uma proposição de uma destrutibilidade nãoviolenta, e isto está profundamente relacionado com a ideia que Benjamin guarda sobre Deus e sobre o mandamento como algo que se diferencia do direito positivo, sendo "não coercitivo e inimputável", e esta destrutibilidade não-violenta, este mandamento não vinculante, é o que Benjamin denominará por violência divina, a que "tem o poder de destruir a violência mítica" (BUTLER, 2017, 86) e todos os seus efeitos, sendo o mais fundamental deles a culpa.

Um dos trechos mais fundamentais da série de dicotomias que Benjamin estabelece no ensaio é aquele em que ele trata sobre o conceito de mera vida (blosse Leben) e a violência sangrenta. Insistindo na diferenciação, escreve Benjamin: "A violência mítica é violência sangrenta exercida, em favor próprio, contra a mera vida;

${ }^{27} \mathrm{O}$ conceito é repetido 11 vezes no ensaio por Benjamin, o que demonstra certa relevância de reflexão, mesmo que em contextos diferentes.

28 Sobre a ideia do "puro" (reine) nos textos do jovem Benjamin, é interessante o comentário de Agamben no Estado de Exceção ao associar este conceito a cartas e outros textos da mesma época do texto. Ver: AGAMBEN, Giorgio. Estado de Exceção. São Paulo: Boitempo, 2011, 94-95.

Professor Doutor na Universidade Federal do Pará, vinculado ao Instituto de Ciências Jurídicas. Leciona no Programa de pós-graduação em Direito da mesma Universidade. Brasileiro, residente em Belém. E-mail: ricardoadt@gmail.com

Graduando em Direito pela Universidade Federal do Pará (UFPA) e pesquisador de Iniciação Científica PIBIC/FAPESPA em Filosofia pela mesma universidade. Brasileiro, residente em Belém. E-mail: nilton.chagas@hotmail.com 
a violência divina e pura se exerce contra toda a vida, em favor do vivente" (BENJAMIN, 2011, 151-152, grifo nosso). Aqui temos uma série de elementos interessantes. Vejamos, por exemplo, o estabelecer de que a violência mítica é de caráter sangrento e uma violência divina que é "letal de maneira não-sangrenta" (Idem, 151). Se apreendermos isso de maneira não-alegórica, como talvez pretenda Benjamin, pode-se pensar que uma violência não-sangrenta é justamente aquela que não se dirige contra corpos, o que endossaria a perspectiva de que tal tipo de violência tem caráter destrutivo, porém não-violento.

Outro ponto interessante (e extremamente obscuro) são os conceitos de mera vida, vida e vivente. $O$ direito positivo exerce violência contra a mera vida em favor próprio, ou seja, marcadamente sem justificação que não sua própria instauração e manutenção. Mas o que podemos aprender por mera vida? Seria, por exemplo, a apropriação de Agamben de blosse Leben como vida nua, aquela destituída de valor político (porém, absolutamente politizada), aquela que pode ser morta sem que haja homicídio (AGAMBEN, 2010, 12), uma interessante compreensão? Além disso, o que é a vida contra a qual a violência divina se exerce em nome do vivente? No que a vida se diferencia do vivente? Estaria isto ligado à referência que Benjamin faz à Coré no fim de seu ensaio?

Certamente não se tem resposta definitiva para tais questões. Butler segue a argumentação de que a "vida em si", ${ }^{29}$ como sacralidade não pode ser fundamento para se contrapor ao direito positivo, mas somente aquilo que Benjamin chama por "alma do vivente", pois a destituição do direito atuaria em favor desta. O mandamento que não é lei deve ser, portanto,

\begin{abstract}
um tipo de violência que se contrapõe à violência legal da mesma maneira que a mera vida controlada pelo direito positivo difere da alma do vivente, que continua sendo o foco da violência divina [...] Benjamin parece interpretar o mandamento de não matar como um mandamento de não matar a alma do vivente e, portanto, um mandamento para exercer violência contra o direito positivo que é responsável por tal assassinato (BUTLER, 2017, 87)
\end{abstract}

\footnotetext{
29 "É falsa e vil a proposição de que a existência teria um valor mais alto do que a existência justa quando existência significar nada mais do que mera vida" (BENJAMIN, 2011, 153-154)

Professor Doutor na Universidade Federal do Pará, vinculado ao Instituto de Ciências Jurídicas. Leciona no Programa de pós-graduação em Direito da mesma Universidade. Brasileiro, residente em Belém. E-mail: ricardoadt@gmail.com

Graduando em Direito pela Universidade Federal do Pará (UFPA) e pesquisador de Iniciação Científica PIBIC/FAPESPA em Filosofia pela mesma universidade. Brasileiro, residente em Belém. E-mail: nilton.chagas@hotmail.com
} 
Portanto, ao contrapor a alma do vivente e a mera vida, e associá-las, respectivamente, à violência divina e à violência mítica, pode-se compreender que Butler guarda consigo a percepção de que a alma do vivente seria o tipo de vida para além da violência do direito, para além de sua forma de constituição subjetiva, enquanto a mera vida "claramente não se trata de uma vida simplesmente biológica, ${ }^{30}$ mas do estado mortuoso induzido pela culpa" (Idem), ou seja, a forma de vida regida pela violência mítica. Cita-se Butler (Idem, 88, grifo nosso) novamente:

\begin{abstract}
O desejo de libertar a vida de uma culpa assegurada pelo contrato legal com - Estado seria um desejo que dá origem a uma violência contra a violência, uma violência que busca libertar a vida de um contrato de morte com o direito, uma morte da alma vivente pela força cada vez mais dura da culpa. Essa é a violência divina que se move sobre a humanidade, como uma tempestade, para apagar todos os traços de culpa, uma força expiadora divina, portanto, e não uma penitência.
\end{abstract}

Desse modo, o ponto leitura do ensaio como um texto que dá direcionamento a um pensar sobre a não-violência é que a violência divina, mesmo que carregue este nome consigo, não é uma violência contra corpos (mesmo que este não seja o único modo de violência possível, apesar de mais emblemático), contra a vida orgânica, mas sim contra um processo de subjetivação, aquele que produz a mera vida de um "estado mortuoso induzido pela culpa"; dessa forma, é uma violência contra uma estrutura, um quadro de referência, a estrutura do direito como poder e violência efetiva sobre as vidas, em favor do vivente e não-sangrenta. A violência divina, embora possa-se classificá-la como violência, e que seja "justificado designar essa violência também como aniquiladora", ela não o é absolutamente, senão apenas "de maneira relativa, com respeito a bens, direito, vida e que tais, nunca de maneira

\footnotetext{
${ }^{30}$ Aqui Butler faz clara referência à apropriação de Agamben sobre o conceito de blosse Leben; para além de suas discordâncias político-filosóficas explicitadas em outros textos quanto à ideia de vida nua, Butler contrapõe aqui a caracterização inicial de Agamben sobre a vida nua enquanto zoé, vida natural politicamente desqualificada (mesmo que politizada pela exclusão) frente às forças jurídico-políticas do Estado de Exceção. Diz, por exemplo Jeanne Marie Gagnebin: "a 'mera vida' de Benjamin não pode ser identificada de maneira imediata com a 'vida nua', como o faz Giogio Agamben refletindo sobre a biopolítica contemporânea" (GAGNEBIN, 2014, 55). Butler está justamente dizendo que a mera vida não é vida natural politicamente desqualificada, mas um processo de subjetivação dentro de um enquadramento legal caracterizado pela culpa fundante.
}

Professor Doutor na Universidade Federal do Pará, vinculado ao Instituto de Ciências Jurídicas. Leciona no Programa de pós-graduação em Direito da mesma Universidade. Brasileiro, residente em Belém. E-mail: ricardoadt@gmail.com

Graduando em Direito pela Universidade Federal do Pará (UFPA) e pesquisador de Iniciação Científica PIBIC/FAPESPA em Filosofia pela mesma universidade. Brasileiro, residente em Belém. E-mail: nilton.chagas@hotmail.com 
absoluta com respeito à alma do vivente." Mas, como questiona Butler, o que significaria de maneira relativa? Haveria, portanto, uma liberdade condicional para que os homens façam o uso de violência letal uns contra os outros? Segue Benjamin (2011, 152):

e ela [a violência pura ou divina] será contestada com a observação de que, segundo suas deduções, ela permitiria também, condicionalmente, aos homens o uso da violência letal uns contra os outros. Isto, entretanto, não pode ser admitido. Pois a pergunta "tenho permissão para matar?" recebe irrevogavelmente a resposta na forma do mandamento "Não matarás!".

Apesar desta resposta, que sem contextualização poderia dar a entender que o mandamento teria força de lei, Benjamin prossegue dizendo que

\begin{abstract}
do mandamento não pode ser deduzido nenhum julgamento do ato [...] $\mathrm{O}$ mandamento não existe como medida de julgamento, e sim como diretriz de ação para a pessoa ou comunidade que age, as quais, na sua solidão, têm de se confrontar com ele e assumir, em casos extremos, a responsabilidade de não levá-lo em conta
\end{abstract}

Estas citações são extremamente interessantes para o que se vinha tentando demonstrar neste texto, e para algumas perguntas postas inicialmente sobre o ensaio de Benjamin. Como já dito acima de algum modo, sendo algo que corrobora para a interpretação de Butler, parece claro que Benjamin parte de um outro pensar a respeito do judaísmo e de um ethos judaico, não partindo de certo senso comum em que o Deus judaico seria compreendido como o Deus vingativo, punidor, produtor de culpa. Há uma inversão desta apreensão da Torá, possivelmente muito marcada pelos escritos de Rosenzweig. Outro ponto relacionado com esta ideia de Deus é o afastar de seu mandamento como julgamento com força de lei, contrapondo-se a isso uma diretriz de ação que deve ser confrontada, ou, como diz Butler, o mandamento não guarda consigo força de polícia, mas sim uma forma de interpelação ética, pois o mandamento contra o matar não é baseado em uma suposta sacralidade da vida, "mas em outra coisa" (BUTLER, 2017, 89). Talvez esta outra coisa seja a transitoriedade da vida enquanto aquilo que podemos denominar por felicidade, ou, para usar vocabulário deste ensaio de Benjamin, a alma do vivente.

Com isso, retoma-se certa perspectiva circular e inevitável presente no ensaio de Benjamin, justamente as figuras da teologia e do messianismo. O linguajar de Deus Professor Doutor na Universidade Federal do Pará, vinculado ao Instituto de Ciências Jurídicas. Leciona no Programa de pós-graduação em Direito da mesma Universidade. Brasileiro, residente em Belém. E-mail: ricardoadt@gmail.com

Graduando em Direito pela Universidade Federal do Pará (UFPA) e pesquisador de Iniciação Científica PIBIC/FAPESPA em Filosofia pela mesma universidade. Brasileiro, residente em Belém. E-mail: nilton.chagas@hotmail.com 
e de violência divina, contrapondo-se à lei e à violência mítica produzida por esta (portanto, uma violência contra a violência) é marcada por uma série de paradoxalidades, - o que não significa, propriamente, que o ensaio de Benjamin seja contraditório. As paradoxalidades são propositais. Como nos diz Jeanne Marie Gagnebin $(2014,194)$, em interpretação que não conflita com a de Butler neste ponto:

\begin{abstract}
a teologia não é uma construção especulativa dogmática, mas, antes e acima de tudo, um discurso profundamente paradoxal. Trata-se de um discurso ou saber (logos) que, de antemão, tem consciência de que seu objeto - Deus (theos) - Ihe escapa, pois está muito além (ou aquém) de qualquer objetividade. Assim, a teologia seria o exemplo privilegiado da dinâmica profunda que habita a linguagem humana quando esta se empenha em dizer verdadeiramente seu fundamento, em descrever seu objeto e, não o conseguindo, não cansa de inventar novas figuras e novos sentidos.
\end{abstract}

O esclarecimento que faz Jeanne Marie sobre estes pontos é fundamental para pensarmos as categorias de Benjamin em seu ensaio, assim como a apropriação que Butler o faz dele. É impossível pensar as figuras da violência mítica e da violência divina sem levar em conta esta fundamentalidade paradoxal da teologia como alegoria teórica em Benjamin, assim como seria impossível compreender um mandamento não-vinculante, um imperativo não-imperativo, não-coercitivo sem pensar na construção de novas figuras e sentidos a partir de uma aparente paradoxalidade. Seria impossível apreender fundamentalmente, portanto, o pensar de uma violência nãosangrenta, que age em nome dos viventes e, em última instância, o pensar de uma violência não-violenta sem levar em conta tal característica necessária da teologia em Benjamin como discurso paradoxal e criativo ${ }^{31}$ de novos sentidos, novos pensares sobre a temporalidade, a forma de vida relacional, sobre a transitoriedade messiânica eterna - impedida pelo enrijecimento do direito - como via de abertura, como "porta estreita" (BENJAMIN, 2017, 20) por onde pode entrar um novo ethos que talvez possamos chamar de felicidade, abalando "os edifícios tão bem construídos dos

31 Discurso que se define por uma insuficiência essencial que se constitui "positivamente em redor dessa ausência" (GAGNEBIN, 2014, 194) e, por isso, criativo.

Professor Doutor na Universidade Federal do Pará, vinculado ao Instituto de Ciências Jurídicas. Leciona no Programa de pós-graduação em Direito da mesma Universidade. Brasileiro, residente em Belém. E-mail: ricardoadt@gmail.com

Graduando em Direito pela Universidade Federal do Pará (UFPA) e pesquisador de Iniciação Científica PIBIC/FAPESPA em Filosofia pela mesma universidade. Brasileiro, residente em Belém. E-mail: nilton.chagas@hotmail.com 
sistemas lógicos, especulativos ou políticos" (GAGNEBIN, 2014, 195); felicidade não como promessa, mas como expressão de uma potência do tempo-do-agora.

\section{CONCLUSÃO}

Como tentamos demonstrar, Butler estaria lendo possibilidades de uma "ode" à não-violência em Para a crítica da violência, uma busca por potencialidades de um ethos pós-jurídico, pós-estatal e não-violento, a partir de novas perspectivas a respeito do judaísmo e de suas categorias teológico-políticas. E, claro, esta interpretação não nasce de um trabalho de comentadora de Benjamin, de um trabalho de uma exegeta, mas da abertura de possibilidades interpretativas que dialoguem com seu projeto político-filosófico a partir do diagnóstico que ela mesma faz. Butler não está "aplicando" Benjamin ao contemporâneo, não está transpondo seus escritos como verdadeira chave de leitura do presente; o que Butler faz é propriamente o trabalho de uma filósofa crítica inquieta com as questões que afligem o presente e, a partir disso, cria diálogos sobre certos conceitos e categorias que podem nos ajudar a compreender problemas políticos concretos. Não à toa ela abre uma questão, ao fim do capítulo destrinchado acima, que reúne justamente as inquietudes políticas com as categorias de Benjamin para que ele nos ajude a pensar sobre, por exemplo, a guerra do Líbano em 2006, ou a guerra contra Gaza em 2008-2009, ou até mesmo sobre o discurso público justificador de suas atividades bélicas pelo Estado de Israel a partir da evocação da ideia de "autodefesa" (BUTLER, 2017, 97), problemáticas diretamente relacionadas em como a judaicidade e o sionismo são pensados na esfera pública. Crê-se que seja este, verdadeiramente, o trabalho da crítica pública, neste caso, da crítica da violência.

De maneira latente, gostaríamos de sustentar que, para além desta crítica da violência, do progresso, da "organização política, nacionalismo, imigrações, diferenças culturais, sexualidade, secularismo, religiosidade e modernidade" (BRUM, 2018, 102), Benjamin auxilia Butler, a partir de um abrir espaço para o refletir sobre a não-violência, a pensar as questões do coletivo aliado à memória, o que influiria em

Professor Doutor na Universidade Federal do Pará, vinculado ao Instituto de Ciências Jurídicas. Leciona no Programa de pós-graduação em Direito da mesma Universidade. Brasileiro, residente em Belém. E-mail: ricardoadt@gmail.com

Graduando em Direito pela Universidade Federal do Pará (UFPA) e pesquisador de Iniciação Científica PIBIC/FAPESPA em Filosofia pela mesma universidade. Brasileiro, residente em Belém. 
suas teorizações sobre o luto. Para além da compreensão de que a centralidade do luto na filosofia política de Judith Butler seria um deslocamento da centralidade da morte em Hegel e uma apropriação da compreensão freudiana (RODRIGUES, 2017, 330), gostaríamos de apontar para a centralidade da memória e da restauração ${ }^{32}$ enquanto ato coletivo para o ato político ${ }^{33}$ do luto. $O$ assumir do luto como ato político é compreender a "dimensão coletiva da perda" (RODRIGUES, 2020, 135), marcada fundamentalmente por uma ação voltada contra o esquecimento e em favor da memória (sempre em seu significado coletivo). Como a própria Butler aponta em relação a sua reflexão sobre Benjamin, além da promoção de uma crítica pública contra a violência, também busca "articular os valores da coabitação e da rememoração" (BUTLER, 2017, 103, grifo nosso). Coabitação e rememoração juntas, marcando justamente a característica de um ato político do coletivo. Benjamin, ao retornar da Primeira Guerra, falou fundamentalmente sobre a incapacidade de elaboração das experiências traumáticas presenciadas - daí saem os textos Experiência e Pobreza e O Narrador. Com isto, ele estava preocupado, no fundo, com "o apagamento das memórias coletivas" (RODRIGUES, 2020, 138). A temática, portanto, é central para qualquer reflexão que parta de Benjamin, que faz da rememoração uma prática - prática esta que não visa "abolir a morte pessoal, inevitável, mas de transformá-la no objeto de um lembrar permanente, constante (...) de opor à inevitabilidade da morte singular a tenacidade da memória humana, imagem utópica de uma imortalidade coletiva” (GAGNEBIN, 2014, 15, grifo nosso). Isto abre um diálogo inafastável com a compreensão que Butler traz sobre o luto, e que movimenta, de maneira necessária, o pensar de uma ética marcada por certa tradição judaica, construída a partir de uma radicalização do apelo pela rememoração ${ }^{34}$ (eingedenken) e relacionado diretamente com a não-violência.

\footnotetext{
32 "A restauração indica, portanto, o reconhecimento da perda, a recordação de uma ordem anterior e a fragilidade desta ordem" (GAGNEBIN, 1999, 14).

${ }_{33}$ Sobre o luto como ato político, ver: https://brasil.elpais.com/babelia/2020-07-10/judith-butler-dequem-sao-as-vidas-consideradas-choraveis-em-nosso-mundo-publico.html
}

${ }^{34}$ Como nos esclarece Jeanne Marie Gagnebin $(1999,14)$, a rememoração em Benjamin é categoria "oriunda, sem dúvida nenhuma, da tradição religiosa judaica". Bernd Witte, de alguma maneira, também faz referência ao caráter teológico-judaico da "lembrança" contra o "esquecimento" (WITTE, 2017, 119).

Professor Doutor na Universidade Federal do Pará, vinculado ao Instituto de Ciências Jurídicas.

Leciona no Programa de pós-graduação em Direito da mesma Universidade. Brasileiro, residente em Belém. E-mail: ricardoadt@gmail.com

Graduando em Direito pela Universidade Federal do Pará (UFPA) e pesquisador de Iniciação Científica PIBIC/FAPESPA em Filosofia pela mesma universidade. Brasileiro, residente em Belém. 
Mas, além disso, a interpretação que Butler faz de Benjamin é uma boa interpretação? Por que, como ela mesma diz, é tão contestada? Bem, para que a primeira questão seja respondida, teríamos que partir de uma determinada concepção sobre o que é interpretar e o que faz desse ato um ato "bom". Não temos, de nenhum modo, tal pretensão de avaliação - seja porque seria desinteressante, seja porque inócua. Quanto à segunda pergunta, poderíamos apontar duas vias: a leitura de Butler desagrada por ser, segundo seus críticos, imprecisa e infiel ao texto ou desagrada do ponto de vista sobre a qual projeto político-filosófico esta interpretação serve. Às duas objeções poderíamos dedicar outros dois textos. Porém, o que não se pode negar é a dinâmica e a importância do trabalho crítico de Butler em nome de perspectivas e "fins" que seriam comuns a maioria de seus críticos como, por exemplo (e é isso que é mobilizado de fundo por Butler), a busca por uma igualdade radical, seja materialmente, seja no valor que as vidas assumem no espaço público. No fundo, é disso que se trata uma ética da não-violência tal qual teorizada por Butler; pois, como o próprio Benjamin nos ensina, da "perspectiva da violência (...) não existe igualdade" (BENJAMIN, 2011,149).

Quanto à questão da precisão ou imprecisão da interpretação em relação ao ensaio, pode-se dizer que há uma indeterminação; há uma série de elementos biográficos e no próprio texto que confirmam sua perspectiva de um Benjamin "teórico da não-violência", assim como existem elementos profundamente ambíguos sobre sua posição do uso político da violência. Mas cremos que tal perspectiva é profundamente desinteressante do ponto de vista de uma teoria que se pretende crítica. Sobre tal ponto, muito mais interessante é a lição que Paulo Arantes nos legou sobre a recepção francesa de Hegel, em sua fidelidade infiel, que podemos aqui transformar: mais vale, precisamente, um Benjamin "errado", mas vivo. Cremos que Judith Butler soube mobilizar radicalmente esta vivacidade.

\section{REFERÊNCIAS}

Professor Doutor na Universidade Federal do Pará, vinculado ao Instituto de Ciências Jurídicas. Leciona no Programa de pós-graduação em Direito da mesma Universidade. Brasileiro, residente em Belém. E-mail: ricardoadt@gmail.com

Graduando em Direito pela Universidade Federal do Pará (UFPA) e pesquisador de Iniciação Científica PIBIC/FAPESPA em Filosofia pela mesma universidade. Brasileiro, residente em Belém. E-mail: nilton.chagas@hotmail.com 
AGAMBEN, Giorgio. Estado de exceção. São Paulo: Boitempo, 2016.

AGAMBEN, Giorgio. Homo sacer: O poder soberano e a vida nua. Belo Horizonte: Editora UFMG, 2014.

BENJAMIN, Walter. Destino e caráter. In__: Escritos sobre mito e linguagem. Organização de Jeanne Marie Gagnebin. Tradução de Susana Kampff e Ernani Chaves. São Paulo: Editora 34, 2011.

BENJAMIN, Walter. Para uma crítica da violência. In__: Escritos sobre mito e linguagem. Organização de Jeanne Marie Gagnebin. Tradução de Susana Kampff e Ernani Chaves. São Paulo: Editora 34, 2011.

BENJAMIN, Walter. Fragmento Teológico-Político. In__: O Anjo da História. Belo Horizonte: Editora Autêntica.

BENJAMIN, Walter. Teses sobre o conceito de História. In__: O Anjo da História. Belo Horizonte: Editora Autêntica.

BERND, Witte. Walter Benjamin: uma biografia. Belo Horizonte: Autêntica, 2017.

BUTLER, Judith. Caminhos divergentes: judaicidade e crítica do sionismo. São Paulo: Boitempo, 2017.

BUTLER, Judith. Precarious Life: The powers of Mourning and Violence. New York: Verso, 2004.

BUTLER, Judith. The Force of Non-Violence. New York: Verso, 2020.

BUTLER, Judith. What is critique? An Essay on Foucault's Virtue. Londres: Brasil Blackwell, 2001.

BRUM, Benjamin. Judith Butler leitora de Walter Benjamin: para uma crítica das políticas progressistas e identitárias. São Paulo: Cadernos de Filosofia Alemã, v. $24 ;$ n.1, p. 101-114.

CHAVES, Ernani. Mito e política: notas sobre o conceito de destino no "jovem" Benjamin. São Paulo: Trans/Form/Ação, 1994.

Professor Doutor na Universidade Federal do Pará, vinculado ao Instituto de Ciências Jurídicas. Leciona no Programa de pós-graduação em Direito da mesma Universidade. Brasileiro, residente em Belém. E-mail: ricardoadt@gmail.com

Graduando em Direito pela Universidade Federal do Pará (UFPA) e pesquisador de Iniciação Científica PIBIC/FAPESPA em Filosofia pela mesma universidade. Brasileiro, residente em Belém. E-mail: nilton.chagas@hotmail.com 
CHAVES, Ernani. No limiar do moderno: ensaios sobre Nietzsche e Walter Benjamin. Belém: Paka-tatu, 2003.

CHAVES, Ernani. O "silêncio do trágico": Walter Benjamin entre Franz Rosenzweig e Friedrich Nietzsche. Lisboa: Philosophica, 2015.

DUARTE, André. Judith Butler e Hannah Arendt em diálogo: repensar a ética e a política. In__: Vida e Liberdade: entre a ética e a política. Cesar Candiotto; Jelson Oliveira. (Org.). 1ed.Curitiba: PUCPRESS, 2016, v. 1, p. 311-336.

GAGNEBIN, Jeanne Marie. História e narração em Walter Benjamin. São Paulo: Editora Perspectiva, 1999.

GAGNEBIN, Jeanne Marie. Limiar, aura e rememoração. São Paulo: Editora 34, 2014.

GAGNEBIN, Jeanne Marie. Walter Benjamin e os cacos da história. São Paulo: N1 Edições, 2018.

RODRIGUES, Carla. A função do luto na filosofia política de Judith Butler. In__:

Deleuze, desconstrução e alteridade. CORREIA, A.; HADDOCK-LOBO, R.; SILVA, C. V. (org ). Coleção XV. II Encontro ANPOF, ANPOF, 2017, p. 329-339.

RODRIGUES, Carla. Os fins do luto. In__: Revista Serrote, São Paulo, v. 1, 2020. p. $134-143$.

SAID, Edward. Freud e os não-europeus. São Paulo: Boitempo, 2004.

VIEIRA, Rafael Barros. Walter Benjamin: O direito, a política e a ascensão e colapso da República de Weimar (1918/9-1933). Rio de Janeiro, 2016. 248p. Tese de Doutorado - Departamento de Direito. Pontifícia Universidade Católica do Rio de Janeiro.

WEITZ, Eric. Weimar Germany: promise and tragedy. Princeton: Princeton University Press, 2007.

Professor Doutor na Universidade Federal do Pará, vinculado ao Instituto de Ciências Jurídicas. Leciona no Programa de pós-graduação em Direito da mesma Universidade. Brasileiro, residente em Belém. E-mail: ricardoadt@gmail.com

Graduando em Direito pela Universidade Federal do Pará (UFPA) e pesquisador de Iniciação Científica PIBIC/FAPESPA em Filosofia pela mesma universidade. Brasileiro, residente em Belém. E-mail: nilton.chagas@hotmail.com 